\title{
SMALL MAMMAL MOVEMENTS AND FIRE HISTORY: TESTING THE LONG-TERM EFFECTS OF THE 1988 HUCKLEBERRY MOUNTAIN FIRE
}

\author{
Hayley C. LANiER \ DePartment of Zoology AND Physiology \\ UNIVERSITY OF WYOMING $\uparrow$ CASPER, WY \\ Lorraine L. CARVER ^ DePartment OF ZOOLOGY AND PHySiology \\ UNIVERSITY OF WYOMING $\diamond$ CASPER, WY \\ ZACHARY P. ROEHRS $\downarrow$ SCHOOL OF MATH AND SCIENCES

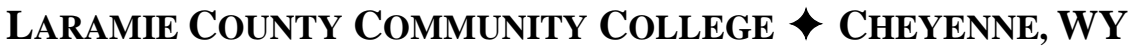 \\ MEREDITH A. ROEHRS $\downarrow$ SCHOOL OF MATH AND SCIENCES \\ LARAmie County Community College $\diamond$ CHEYenne, WY

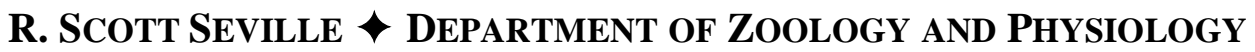 \\ UNIVERSITY OF WYOMING • CASPER, WY
}

\section{$\uparrow \quad$ AbSTRACT}

Fires are an important ecological force shaping biological communities in western North America. Fires change landscapes in ways which influence the relative abundance and activities of the organisms occurring in those habitats. Preliminary results from previous work suggest the stage of fire succession may influence individual movements on the landscape. As part of a long-term study of the 1988 Yellowstone fires along the John D. Rockefeller, Jr. Memorial Parkway, we set out to examine these patterns in more detail to (1) test whether the two dominant small mammal species were moving different distances based upon the stage of succession in a particular habitat, and (2) determine the role of habitat complexity, resource types, and species abundance in driving these patterns. Using movement distances from capture-recapture data and fluorescent powder tracking of individuals we compared movement distances and habitat usage between mid-
\end{abstract}

succession and late-succession trapping grids for redbacked voles (Myodes gapperi) and deer mice (Peromyscus maniculatus). The results suggest deer mice, some of the first colonizers to burned habitat, are moving farther than red-backed voles, and move farther in burned habitats than in unburned habitats. Red-backed voles exhibit slightly, but not significantly, longer movements in burned habitats. Powder tracking results suggest habitat complexity, in particular the quantity of coarse woody debris, may partially explain the differences in movement patterns by burn history. These results are important for understanding the long-lasting impacts of fire history on population and community patterns.

\section{$\uparrow \quad$ INTRODUCTION}

Fire disturbance continues to be an important force shaping communities in the Intermountain West. Fire disturbances thin out old-growth forests, redistribute nutrients, increase landscape variability in 
plant communities, and shape vegetation structure (reviewed in Wallace 2004). Despite the widely recognized importance of fire in these ecosystems (see review in Romme et al. 2011) few studies have followed long-term responses (>10 years) in small mammal communities, or have evaluated how fire history shapes how individuals interact on the landscape. Given the varied history of fires across the Yellowstone region, evaluating the role fire may be playing in shaping animal movements and community connectivity is important to understanding ecosystem health. Previous UW/NPS work by Stanton et al. (1990, 1991), Spildie (1994), Seville et al. (1997), Stanton et al. (1998), Burt et al. (2009, 2010), and Lanier et al. (2014) at Huckleberry Mountain, Wyoming has built a baseline for understanding how small mammal communities and habitat structure have changed over a 26-year post-fire interval. These small mammal and vegetation surveys, begun after the extensive 1988 fire season, have provided biologists with the unique opportunity to study the short and long-term effects of a natural disturbance on community dynamics and the relationships between successional stages of the vegetative community and the corresponding faunal community structure. As predicted by Taylor (1973), small mammal species diversity was highest 25 years after fires; however, diversity in unburned plots has increased over the same time period, species evenness and abundance continues to differ between burned and unburned plots, and the increases in diversity do not yet show a clear leveling out. Further unknown is how these changes in abundance and habitat during post-fire succession impact mammal movements, and longterm ecological responses in small mammal communities.

Most fire-succession studies on small mammals (rodents and shrews) have focused on the early stages (0-10 years), providing important evidence on initial community structure (e.g., Fisher and Wilkinson 2005). Early on, the initiation stage ( 0 10 years post-burn; Lee 2002) often include changes in relative abundance within the community rather than outright species replacement. The deer mouse (Peromyscus maniculatus), a generalist, typically responds positively in the years following fire and is often the most numerically dominant species. This was true for our study sites, with initially large populations of deer mice, which were 3 times as abundant in the burned habitats than in the unburned habitats (Stanton et al. 1991). The southern red-backed vole (Myodes gapperi), another numerically dominant species in the GYE, tends to be an old-growth specialist, but can sometimes recolonize rapidly (see Fisher and Wilkinson 2005). Red-backed voles were present but at low relative abundance (approximately $25 \%$ that of deer mice) within the communities on our study sites over the initial 3 years after the burn (Stanton et al. 1991). Given grasses are common in the years immediately following a fire, the presence of grassland species such as jumping mice (Zapus spp.) and voles (Phenacomys intermedius and Microtus spp.) is often initially increased. These grassland specialists were initially detected on our study sites within the first 10 years after the burn, but comprise a smaller proportion of the total small mammal community (Seville et al. 1997). Less is known regarding the responses of insectivores, particularly shrews, in the initiation stage; however, the more xeric conditions predominating post-fire are likely less hospitable to shrews. Initial data from our sites bear this pattern out. For example, Spildie (1994) reported $90 \%(N=40)$ of shrews captured in pitfall or live-traps at the Huckleberry Mountain study sites were mainly captured in control grids (84\%), and no masked shrews (Sorex cinereus) were trapped in burned habitats.

Given the challenges associated with longterm studies, few studies have focused on small mammal responses during the establishment stage (11-25 years post-burn; Lee 2002) in North American ecosystems. In boreal forests, the same species are often present, but relative abundances continue to differ. Roy et al. (1995) showed red backed voles were common, but still less abundant than in old growth stands. Other species, such as meadow voles and jumping mice were uncommon or absent, presumably from habitat changes and limited food resources. Deer mice, though still common, were at a lower relative abundance than in earlier years. Data from our sites support the gradual shift in dominance from redbacked voles to deer mice, with more than twice as many red-backed voles as deer mice captured on the burn sites, despite the fact deer mice were more often captured on burned habitats than on adjacent old growth habitats, 26 years post-burn (Lanier et al. 2014). However, jumping mice and other species of voles maintained or increased in relative abundance during this time period, compared to the first 10 years post-fire (Lanier et al. 2014). Similar to the initiation stage, even less is known regarding the response of insectivores to fire disturbances. Since mammalian insectivores feed on invertebrates, correlative responses to habitat change are less predictable as is the case with granivores and folivores (Kirkland et al. 1997). Nonetheless, as ground cover increases in quantity (leaf litter, etc.) and shifts to a more mesic microhabitat, shrews would be predicted to increase in abundance. During the establishment stage on our sites shrews increased in abundance, comprising $17 \%$ of total captures on the burned grids (Lanier et al. 2014). 
The larger montane shrew ( $S$. monticolus) and the smaller masked shrew ( $S$. cinereus) were both captured on previously burned habitats, as well as in the adjacent old-growth grids (Lanier et al. 2014).

In addition to shifting community structure, fires (and the resulting vegetation and biogeochemical changes) may impact small mammal movements. Small mammal movements and home-range sizes have long been known to reflect multiple factors, such as the availability of resources in space and time (Stapp 1997), pressures from population density (Fretwell and Lucas 1970), and structural complexity (Zollner and Crane 2003). For example, optimum foraging theory (Sinervo 1997) suggests animals will tend to have smaller home ranges and move less when food resources are abundant. High population density will likewise tend to reduce home range size of a species (Fretwell and Lucas 1970). In contrast, high structural complexity (such as presence of many shrubby species and large amounts of coarse woody debris [CWD]) has been shown to increase movement of small mammals (eastern chipmunks), possibly due to reduced predation risk (Zollner and Crane 2003). Analysis of previous re-capture data (Lanier et al. 2014) suggests differential movements in burned than unburned habitats, which may relate to either abundance differences or the presence of more CWD or differential food resources based on burn history.

We used capture-recapture data and powder tracking to examine (1) whether movements in the 2 dominant species (deer mice and red-backed voles) differ by burn history, and (2) if those greater movements are related to either structural complexity (i.e., presence of CWD), population density, or particular resource types (e.g., herbs, grasses, shrubs) within each habitat.

\section{$\uparrow \quad$ METHODS}

\section{Study sites}

Initially established by Stanton et al. (1990) these study sites have been the subject of repeated studies at regular intervals by Stanton et al. (1991), Spildie (1994), Seville et al. (1997), Stanton et al. (1998), Burt et al. (2009, 2010), and Lanier et al. (2014). Although the initial study design involved more survey grids, efforts over the last 20 years have focused primarily on 4 study grids, 2 located in areas burned in the Huckleberry Mountain Fire in 1988 and 2 located in adjacent old-growth habitats (hereafter referred to as burned and control, respectively). Although the control grids are not true controls in the experimental sense, we have opted to retain this term for consistency with previous work. One burned and one control grid is located on the wetter east-facing aspect: east-facing burn (EFB) and east-facing control (EFC) grids. One burned and one control grid are located on the drier west-facing aspect: west-facing burn (WFB) and west-facing control (WFB). Each grid comprises 100 trap stations, located on a 1-ha plot, with each trap station spaced $10 \mathrm{~m}$ apart. Every trap station has a Sherman live trap, for small mammals, and a subset of those trap stations (25/grid) also included a pitfall trap for small mammals and invertebrate communities.

\section{Community survey techniques}

Small mammal surveys consisted of a 4-night trapping period during the months of June, July, and August 2015, following previously established protocols for trap effort (i.e., number of traps/grid, trap nights, and location). Each Sherman trap was baited with rolled oats and peanut butter, opened between 1530 and 1730, and checked between 0500 and 0830 the following day. Traps were closed during the day, as per previous work, to limit trap mortalities. Each trap also contained cotton batting for insulation. Captured animals were uniquely ear-tagged (in one ear) for later identification and injected with a subdermal passive integrated transponder (PIT) tag between the shoulder blades to permit longer-term identification of individuals. Each individual was classified by species, sex, age class (juvenile or adult), and reproductive condition; weighed to the nearest gram; and released where caught. Animals and traps were handled in accordance with current IACUC guidelines for handling small rodents (\#20170517ZR0071-01). As animals were processed (weighed, measured, and tagged) for this study any fecal samples produced were collected in $2 \mathrm{~mL}$ microcentrifuge tubes and later preserved in a $2.5 \%$ w/v aqueous potassium dichromate solution for study of potential protozoan parasite infection (Williams et al. 2010). All traps were cleaned with a viricide at the conclusion of each 4-day trap session. In addition to live traps, a small pitfall trap with propylene glycol was placed at ground level at every 4th trap station (25 pitfalls/grid) to capture voucher specimens, primarily targeting shrews, which are underrepresented in Sherman traps, and the corresponding invertebrate communities.

\section{Tracking movements and microhabitat use}

In addition to trapping to establish community composition and abundance, we conducted several directed tests of small mammal 
movements. First, we used a subset of capturerecapture data to estimate movements for recaptured deer mice and red-backed voles, estimating the withingrid movements of an individual. While recapture data provide some information on the movement among traps, they may not accurately capture the exact distance and microhabitat usage of individuals. Therefore, we compared those movement estimates with information from fluorescent powder tracking. Fluorescent tracking, using fluorescent powder and UV light to reveal and track animal movements, can be used to determine movement of small animals up to $900 \mathrm{~m}$ (Lemen and Freeman 1985). It can also provide information on habitat use, such as what plants are climbed, movements relative to CWD, food consumed, and even where a species burrows (Lemen and Freeman 1985). Trapping effort for powder tracking included 20 additional traps place parallel to the west-facing control and west-facing burn grids for 3 nights in August (the only month with a sufficient number of dry days to trap). Traps were baited with peanut butter and oats, set around 1730, and checked and closed after sundown (2100-0000). Target mammals were captured and processed, as described above, and coated in fluorescent powder taking care to avoid getting powder on the face of the animal. Animals were released at the point of capture, and we returned the following night to track their movements using a UV light. For each individual, we measured total distance traveled, distance traveled using CWD as a percentage of total path distance, and percentage total distance corresponding differing vegetation types (i.e., shrub, grass, CWD, bare ground).

\section{Vegetative structure}

Vegetation characteristics were recorded at a stratified subset of trap stations using 25 different microhabitat measurements following the methods of Deuser and Shugart (1978) and Daubenmire (1959). These included microhabitat characteristics capturing vertical habitat around the trap site: distance to nearest tree and tree size (diameter at breast height, dbh), distance to nearest sapling and size (in dbh), distance to nearest seedling, distance to nearest shrub, and canopy cover. We also recorded ground cover around the trap using a Daubenmire frame, estimating percentage of herbaceous plants, woody plants, grasses, leaf litter, downed logs, and area disturbed by the pitfall trap, each to the nearest $25 \%$ (i.e., $0 \%, 1-$ $25 \%, 26-50 \%, 51-75 \%, 76-100 \%)$. At each chosen station distance to the trap, length, diameter, height from the ground, and decay class of coarse woody debris (i.e., downed $\operatorname{logs}>7.5 \mathrm{~cm}$ in diameter) was quantified for a 5-meter distance in the four cardinal directions following procedures developed by Brown
(1974) and Harmon and Sexton (1996). Microhabitat sampling occurred in July (ground cover and canopy cover measurements, as well as some CWD and distance measurements) and August (CWD and distance measurements only), when herbaceous/grassy vegetation was at maximum height and flowering or fruiting was occurring.

\section{Analyses}

To assess the distances moved by individuals, we evaluated maximum movement distance and average movement based upon traps where an individual was caught, using the $10 \mathrm{~m}$ by $10 \mathrm{~m}$ trapping grid design to estimate distance traveled. Maximum movement distance was taken as greatest total distance between any of the traps in which an individual was caught. Average movement distance was the average of trap-to-trap movements of an individual, taken sequentially as an individual moved around the grid. When an animal was only caught in 2 traps the average and maximum distances were the same. A series of multimodel comparisons (Burnham and Anderson 2002) were run using the $\mathrm{R}$ package MuMIn to examine relative ability of uni- and multivariate models to evaluate distance traveled in the capture/recapture dataset relative to age, sex, grid, aspect, and/or burn history. All single and multiple combinations of variables were compared, with the exception of models including grid and history or grid and slope, which were excluded. For the powder tracking data, we examined percentage of path traveled as the response and individual ID, relationship to $\log$, and vegetation type, and fire history as possible explanatory variables. Multimodel comparisons were run on these data to quantify the relative influence of explanatory variables in path distance using the R package glmulti (Cacagno 2013).

We estimated population abundance as the number of unique captures per species. Diversity within sites was estimated using the Shannon-Wiener Index $\left(H^{\prime}=-\sum p_{i} \log p_{i}\right)$, using only genus for shrews and microtine voles (Microtus spp.) due to difficulty of identifying these species while living. Summary results from microhabitat sampling variables were compared between grids to gauge the amount of difference in vegetative structure and to look for purported relationship between changes in habitat structure and small mammal movements. Significant differences by burn history were examined using a non-parametric Kruskal-Wallis rank-sum test in R. 


\section{$\uparrow \quad$ Results}

Out of 4,800 total trap nights, we captured 1,876 small mammals, of which 919 were unique individuals, representing a minimum of 10 species. Overall, red-backed voles were most abundant and were more than three times as abundant on control grids relative to adjacent burned grids ( $N_{\text {burned }}=109$, $N_{\text {control }}=346$; Figure 1). However, deer mice were more abundant on burned grids than on control grids and equaled or exceeded abundance of red-backed voles on burned grids $\left(N_{\text {burned }}=126, N_{\text {control }}=38\right.$; Figure 1). Shrews (Sorex spp.), mainly Sorex monticolus and $S$. cinereus based on voucher specimens, were captured on all four grids, and shrew abundance was higher on burned grids than on control grids $\left(N_{\text {burned }}=130, N_{\text {control }}=107\right)$. Voles $($ Phenacomys intermedius and Microtus spp.) were only captured on two of the four grids (EFC and WFB), and were slightly more abundant on burned grids $\left(N_{W F B}=13\right.$, $\left.N_{E F C}=10\right)$. Overall, both burned grids had higher Shannon-Wiener diversities $\left(H_{E F B}^{\prime}=1.20, H^{\prime}{ }_{W F B}=\right.$ 1.51) than control grids $\left(H^{\prime}{ }_{E F C}=1.02, H^{\prime}{ }_{W F C}=0.94\right)$, related in part to the presence of pocket gophers (Thomomys talpoides) and greater species evenness in these sites.

Preliminary results of capture-recapture movement metrics suggest both red-backed voles and deer mice moved more than 1.5 times farther in burn grids (average distance moved: $\bar{X}_{D M, b u r n}=37.5 \mathrm{~m}$ vs $\bar{X}_{D M, \text { control }}=23.5 \mathrm{~m}$ and $\bar{X}_{R B V, \text { burn }}=24.6 \mathrm{~m}$ vs. $\bar{X}_{R B V, \text { control }}$ $=16.0 \mathrm{~m}$; Figure 2). However, only differences in movement distances for deer mice were statistically significant by burn history. Because average movement distances and greatest movement distances $\left(\bar{X}_{D M, \text { burn }}=45.3 \mathrm{~m}\right.$ vs $\bar{X}_{D M, \text { control }}=25.6 \mathrm{~m}$ and $\bar{X}_{R B V, \text { burn }}$ $=34.3 \mathrm{~m}$ vs. $\bar{X}_{R B V, \text { control }}=23.0 \mathrm{~m}$ ) were similar with respect to our findings, the average distances will be focused on for other comparisons. Multimodel comparisons suggest these movement differences in deer mice are best explained by burn history (burned vs. unburned), with the top 2 models also including age (Table 1), as individuals initially trapped as juveniles moved slightly farther than adults. In contrast, the best explanatory models for red-backed voles included capture grid, as opposed to burn history (Table 2), sex and age appear in the second- and thirdbest models. Overall, deer mice $\left(\bar{X}_{D M}=34.3 \mathrm{~m}\right)$ moved significantly farther than red-backed voles $\left(\bar{X}_{R B V}=17.8 \mathrm{~m}\right.$; Figure 3).

Due to an exceptionally rainy summer in 2015 we were only able to conduct powder tracking for 120 trap nights. Out of those trapping sessions we

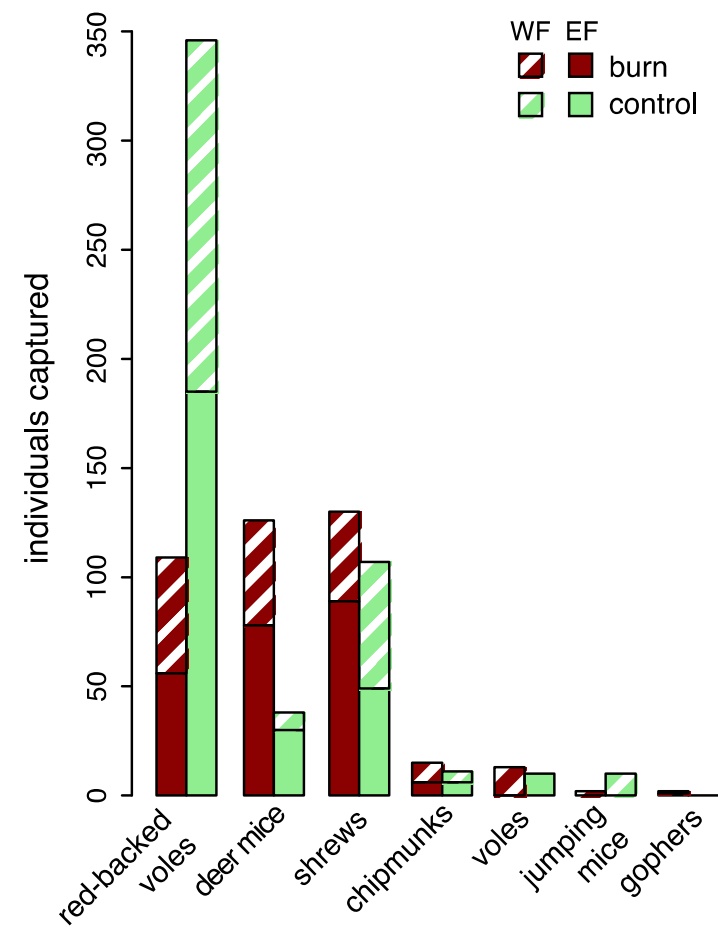

Figure 1. Red-backed voles, deer mice, and shrews (Sorex spp.) dominated small mammal captures, with more redbacked voles in control grids and more deer mice and shrews in burned grids. Other species of voles, both Phenacomys intermedius and Microtus ssp. are combined under 'voles'. West-facing (WF) captures shown with stripes and eastfacing $(\mathrm{EF})$ captures shown with solid colors.

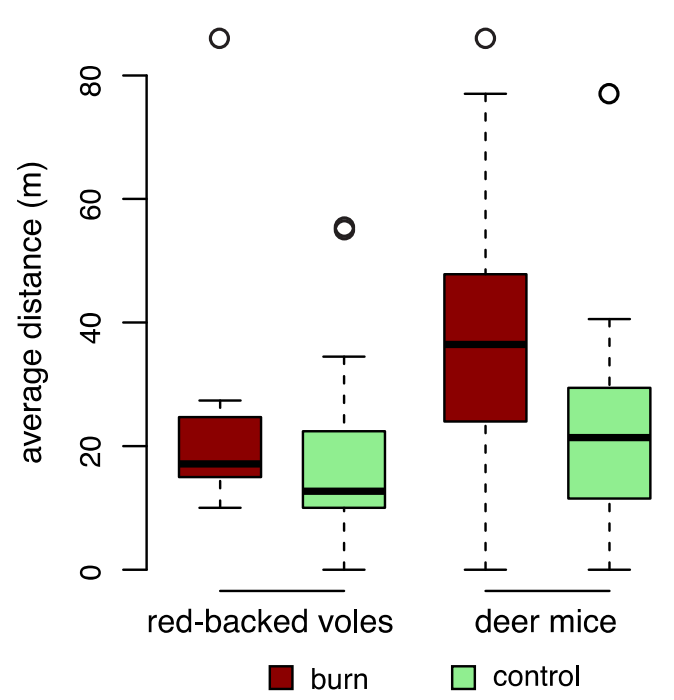

Figure 2. Average movement distances of red-backed voles are greater in burned grids $(24.6 \mathrm{~m})$ than in control grids $(16.0 \mathrm{~m})$, but this difference is not statistically significant $(p=0.1)$. However, deer mice move significantly farther in burned grids $(37.5 \mathrm{~m})$ than in control grids $(23.5 \mathrm{~m} ; p=$ $0.02)$. 
Table 1. The top 5 models based on a multimodel comparison for average movement distances in red-backed voles. Variables included in each top model are shown with a ' + '.

\begin{tabular}{|c|c|c|c|c|c|c|c|c|c|c|}
\hline Intercept & Sex & Age & Grid & History & Aspect & $\mathrm{df}$ & $\log$ Lik & $\mathrm{AICc}$ & delta & weight \\
\hline 43.20 & & & + & & & 5 & -196.778 & 405.0 & 0.00 & 0.248 \\
\hline 41.27 & + & & + & & & 6 & -195.763 & 405.5 & 0.58 & 0.186 \\
\hline 45.20 & & + & + & & & 6 & -195.979 & 406.0 & 1.01 & 0.150 \\
\hline 43.23 & + & + & + & & & 7 & -195.089 & 406.9 & 1.96 & 0.093 \\
\hline 24.64 & & & & + & & 3 & -200.566 & 407.7 & 2.72 & 0.064 \\
\hline
\end{tabular}

Table 2. The top 5 models based on a multimodel comparison for average movement distances in deer mice. Variables included in each top model are shown with a '+'.

\begin{tabular}{|c|c|c|c|c|c|c|c|c|c|c|}
\hline Intercept & Sex & Age & Grid & History & Aspect & $\mathrm{df}$ & logLik & AICc & delta & weight \\
\hline 33.39 & & + & & + & & 4 & -433.204 & 874.9 & 0.00 & 0.289 \\
\hline 29.12 & + & + & & + & & 5 & -432.408 & 875.5 & 0.64 & 0.210 \\
\hline 36.15 & & & & + & & 3 & -435.033 & 876.3 & 1.48 & 0.138 \\
\hline 27.71 & + & + & & + & + & 6 & -432.001 & 877.0 & 2.10 & 0.101 \\
\hline 32.24 & + & & & + & & 4 & -434.369 & 877.2 & 2.33 & 0.090 \\
\hline
\end{tabular}

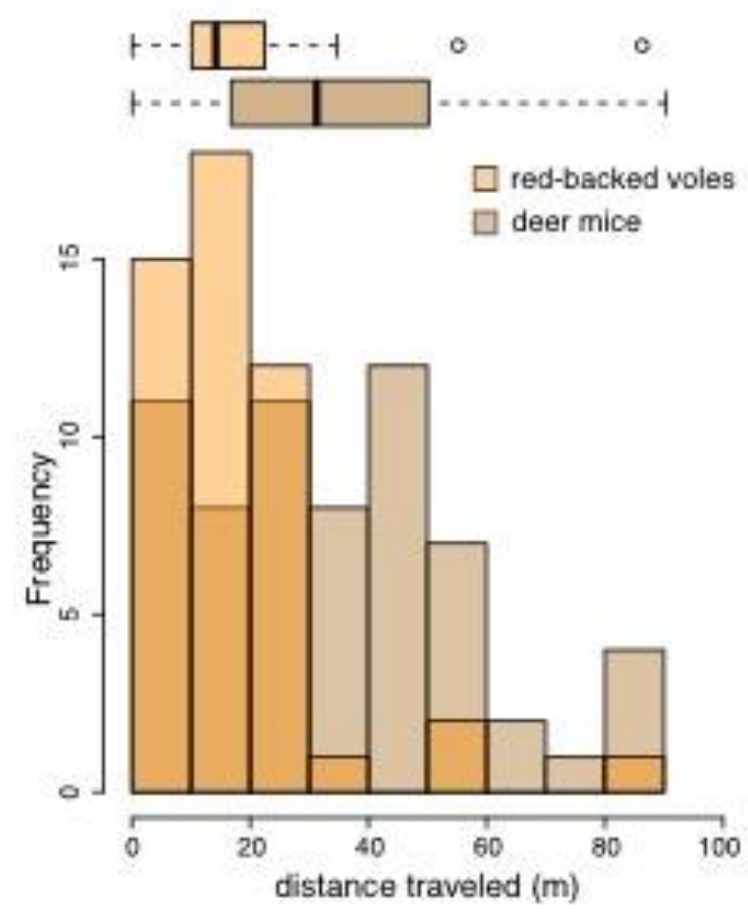

Figure 3. On average, deer mice moved nearly twice as far as red-backed voles (34.26 m vs. $17.79 \mathrm{~m}$, respectively; $p<$ $0.001)$. captured and powdered 9 red-backed voles and 2 deer mice. Overall, trails were followed for an average of $2,026 \mathrm{~cm}$. In red-backed voles, $72.5 \%$ of total trackable trails followed downed logs (CWD), with animals most frequently running on top of logs (as opposed to below or beside logs). Red-backed voles in burned habitats spent a greater proportion of their total path on or near logs than voles in control habitats $\left(\bar{X}_{R B V, \text { burn }}=82.7 \%\right.$ vs. $\bar{X}_{R B V, \text { control }}=67.3 \%$; Figure 4$)$. Much of the red-backed vole movement was through shrubby areas, primarily grouse whortleberry (Vaccinium scoparium), comprising $25 \%$ of total trackable trails, with paths in control habitats moving more frequently through shrubs (Figure 4). However, burned traps also have a greater number of logs $\left(\bar{X}_{\text {burn }}\right.$ $=14.04$ vs $\bar{X}_{\text {control }}=10.14$ within $5 \mathrm{~m}$ of a trap) and shrubs comprise a greater proportion of ground cover around control sites (Figure 5). Contrary to recapture data, powder tracking results suggest red-backed voles were moving slightly, but not significantly farther in control habitats; however, this is based on a small sample size $\left(N_{\text {burn }}=3 ; N_{\text {control }}=6\right)$. While burn history was an important variable, as was presence and use of logs for travel, distance traveled (as a proportion of path length) was best explained by individual-level variation in red-backed voles. Although only 2 deer mice were captured, both in burned grids, an average 


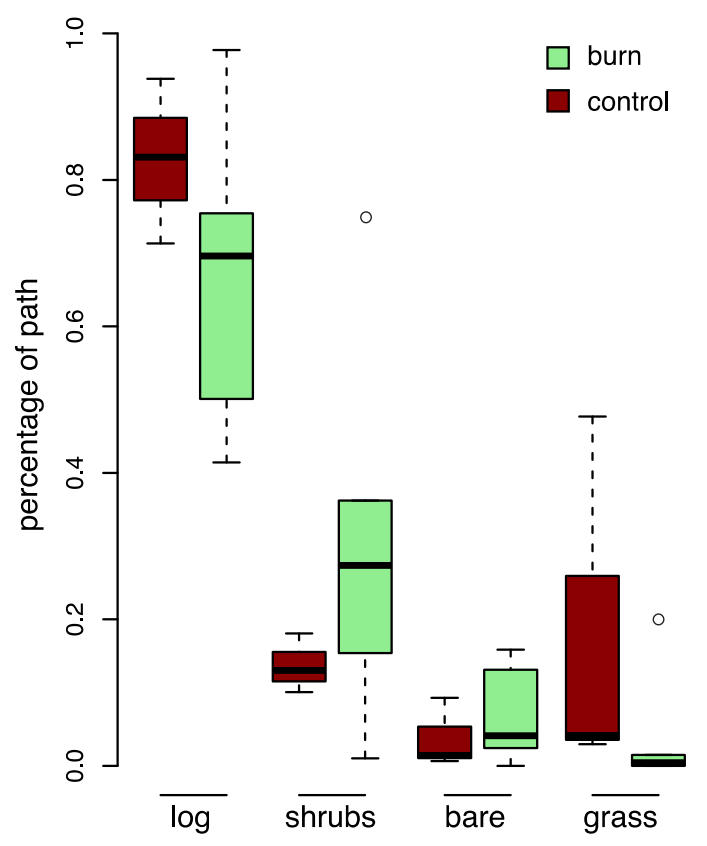

Figure 4. As a percentage of total path, red-backed voles $\left(N_{\text {burn }}=3 ; N_{\text {control }}=6\right)$ mainly followed downed logs (CWD), with shrubs being the second-most traveled habitat. Red-backed voles spent more path distance in grassy habitats on burned grids than on adjacent control habitats.

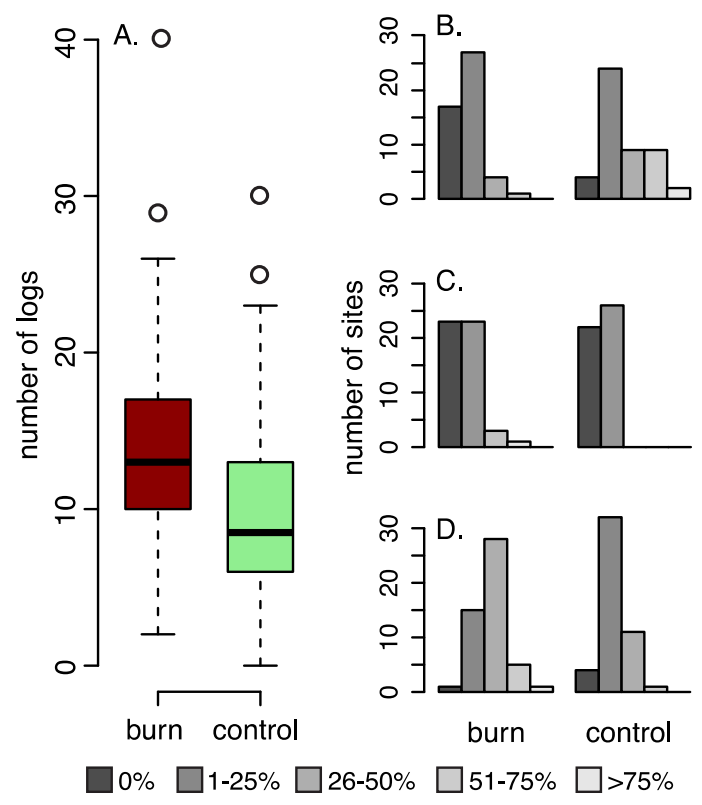

Figure 5. (A) The burned grids had significantly more coarse woody debris (CWD; i.e., logs exceeding $7.5 \mathrm{~cm}$ diameter) around each trap than control grid sites (14.04 vs. $10.14 \operatorname{logs}$ respectively; $p=0.001)$. Ground cover on control sites consisted of generally (B) more shrubs, (C) less bare ground, and (D) slightly less grass than burn sites. of $83 \%$ of their trails followed downed logs (CWD), with the animal often moving on top of the log, and $19 \%$ included shrubby habitats, mostly grouse whortleberry.

\section{$\uparrow \quad$ DISCUSSION}

Preliminary results indicate deer mice, and possibly red-backed voles, are moving farther in burned habitats, a pattern which may be related to greater numbers of downed trees in those areas (i.e., CWD; Figure 5). Powder tracking revealed both species were frequently using CWD for movements, often moving on top of logs, regardless of burn history of the habitat they were in. Taken together, this suggests the habitat complexity hypothesis (Zollner and Crane 2003) may be the best explanation for the home range size and movement distances among habitats. It is worth noting these results do not exclude the abundance hypothesis. While movements are greater on burn grids, habitats where deer mice are more abundant and red-backed voles have lower abundance, small mammals were more abundant overall on control grids (Figure 1). Both species are also frequently moving through shrubs (grouse whortleberry), a pattern which supports previous work proposing presence of shrubs is a good predictor for red-backed vole captures (Lanier et al. 2014). Previous work has suggested these species are not competitively excluding one another, and habitat differences are the result of species-specific preferences (Wolff and Deuser 1986). Because both species appear to be using these habitat features in relative proportion to their presence (i.e., there are no obvious differences in relative path percentage that differs substantially from the proportion of those habitats within each grid), these habitat features may be important throughout the Greater Yellowstone Ecosystem (GYE).

These findings have implications for the role of intermediate levels of fire succession in mediating movements across the landscape in the GYE. If species are traversing greater distances in areas with greater density of downed trees, there may be stronger gene flow and more disease transmission as post-fire succession proceeds in intermountain forests. Deer mice (Peromyscus spp.), in particular, are vectors of numerous zoonotic pathogens with implications for human health, including hantavirus (Hjelle et al. 1995), Lyme disease (Rand et al. 1993), viral encephalitis (Deardorff et al. 2013), and plague (Walsh and Haseeb 2015). Understanding the impacts of landscape structure on these movements and transmission patterns is important for epidemiological 
models of viral infection in deer mice (Langlois et al. 2001). The greater distances moved by deer mice may also partially explain why they are some of the first colonists during post-fire succession (Stanton et al. 1991).

More broadly, our findings contribute to the knowledge of long-term responses to fire in the intermountain west. Despite becoming more similar to the adjacent old-growth grids, i.e., the control grids, habitats burned in 1988 continued to support greater diversity and more evenness of small mammal species. Relative to previous years we seemingly observed a leveling out of species richness, with similar diversity to captures in 2014 (Lanier et al. 2014). This appears to fit the pattern predicted by Taylor (1973), who suggested small mammal richness should plateau around 25-years post-burn. While proportions of redbacked voles have increased on burn sites, they were less abundant in burned habitats than deer mice (Figure 1). Shrews continued to increase on all grids, and were more abundant in burned habitats than deer mice. Overall, small mammal abundance increased nearly $150 \%$ from the previous year (Lanier et al. 2014); however, this pattern was almost entirely driven by increases in red-backed voles, deer mice, and shrews. Interestingly, although these changes may reflect more regional trends in population shifts (small mammals were more abundant in other areas of Wyoming in 2015; M. Ben-David, pers. comm.), these increases were limited to specific grids or habitats on our sites. Red-backed voles only increased greatly on control grids; deer mice increased on two burned and one control grid, and shrews increased greatly on only one of the burned grids. Rare species, such as pocket gophers (Thomomys intermedius) and jumping mice (Zapus princeps), continued to be captured in low numbers, similar to previous years (Lanier et al. 2014). Long-term studies, such as this, are important for revealing the ways in which fire-driving habitat mosaics are influencing and will continue to influence population and community dynamics.

\section{ACKNOWLEDGEMENTS}

We thank the UW-NPS Research Station and Wyoming INBRE (NIH NIGMS P20GM103432) for financial support; Ashkia Campbell and Laura L. Diesburg for assistance with summarizing capture/recapture movement data; Mauro Diaz, James Erdmann, Andy Kulikowski, Samantha Haller, Carolyn Jacobs, Molly Loetscher, Hunter McCurdy, Jessica Marsh, Albert Napolitano, Toni Proescholdt, Dominique Schlumpf, Margo Spurrier, Diane Seville, Jason Turo, Ami Wangeline, and Kayla Wilson for their hard work in the lab and field during the 2015 field season; Merav Ben-David for helpful conversations on regional population trends; Sue Consolo-Murphy and John Stephenson for facilitating collecting permits; and Harold Bergmann and Celeste Havener for assistance with station housing.

\section{Literature Cited}

Brown, J.K. 1974. Handbook for inventorying downed woody material. General Technical Report GTR-INT-16. U.S. Department of Agriculture, Forest Service, Intermountain Forest and Range Experiment Station, Ogden, Utah.

Burnham, K.P., and D.R. Anderson. 2002. Model Selection and Multimodel Inference: A Practical Information-theoretic Approach. 2nd ed. Springer-Verlag, New York.

Burt, M.S., R.S. Seville., W. Cummings, and R. Zook. 2009. Long-term response of small mammal communities to the 1988 Huckleberry Mountain fire. University of Wyoming National Park Service Research Station Annual Report 32:81-87. http://repository.uwyo.edu/cgi/viewcontent.c gi article $=1605 \&$ context $=$ uwnpsrc reports

Burt, M.S., R.S. Seville, Z.P. Roehrs, and R.N. Henley. 2010. Changes within small mammal communities since the 1988 Huckleberry Mountain fire. University of Wyoming National Park Service Research Station Annual Report 33:19-27. http://repository.uwyo.edu/cgi/viewcontent.c gi ?article $=1614 \&$ context $=$ uwnpsrc_reports

Cacagno, V., and C. de Mazancourt. 2010. glmulti: an $\mathrm{R}$ Package for easy automated model selection with (generalized) linear models. Journal of Statistical Software. 34(12):1-29.

Daubenmire, R.F. 1959. A canopy-coverage method of vegetation analysis. Northwest Science 33:43-64.

Deardorff, E.R., R.A. Nofchissey, J.A. Cook, A.G. Hope, A. Tsvetkova, S.L. Talbot, and G.D. Ebel. 2013. Powassan virus in mammals, Alaska and New Mexico, U.S.A., and Russia, 2004-2007. Emerging Infectious Diseases 19:2012-2016.

Deuser, R.D., and H.H. Shugart. 1978. Microhabitats in a forest-floor small mammal fauna. Ecology 59:89-98.

Fretwell S.D., and H.L. Lucas, 1970. On territorial behavior and other factors influencing habitat distribution in birds. Acta Biotheoretica 19:16-36. 
Harmon, M.E., and J. Sexton. 1996. Guidelines for measurements of woody detritus in forest ecosystems. Publication No. 20. U.S. LTER Network Office: University of Washington, Seattle, Washington.

Hjelle, B., S.W. Lee, W. Song, N. Torrez-Martinez, J.W. Song, R. Yanagihara, I. Gavrilovskaya, and E.R. Mackow. 1995. Molecular linkage of hantavirus pulmonary syndrome to the white-footed mouse, Peromyscus leucopus: Genetic characterization of the $\mathrm{M}$ genome of New York virus. Journal of Virology 69:8137-8141.

Kirkland, G.L., R.R. Parmenter, and R.E. Skoog. 1997. A five-species assemblage of shrews from the sagebrush steppe of Wyoming. Journal of Mammalogy 78:83-89.

Langlois, J.P., L. Fahrig, G. Merriam, and H. Artsob. 2001. Landscape structure influences continental distribution of hantavirus in deer mice. Landscape Ecology 16:255-266.

Lanier, H.C., A.J. Kulikowski, Z.P. Roehrs, M.A. Roehrs, and R.S. Seville. 2014. Succession effects on mammal and invertebrate communities 26 years after the 1988 Huckleberry mountain fire. University of Wyoming - National Park Service Research Station Annual Report 37:49-57. http://repository.uwyo.edu/uwnpsrc_reports/

Lee, P. 2002. Stages of forest succession. pp. 3.1-3.3 In: S. Song (ed.) The Ecological Basis for Stand Management in Alberta, Alberta Research Council, Vegreville, Alberta.

Lemen, C.A., and P.W. Freeman. 1985. Tracking mammals with fluorescent pigments: A new technique. Journal of Mammalogy. 66:134136.

Rand, P.W., E.H. Lacombe, R.P. Smith, S.M. Rich, C.W. Kilpatrick, and D. Caporale. 1993. Competence of Peromyscus maniculatus (Rodentia: Cricetidae) as a reservoir host for Borrelia burgdorferi (Spirochaetares: Spirochaetaceae) in the wild. Journal of Medical Entomology 30:614-618.

Romme, W.H., M.S. Boyce, R. Gresswell, E.H. Merrill, G.W. Minshall, C. Whitlock, and M.G. Turner. 2011. Twenty years after the 1988 Yellowstone fires: Lessons about disturbance and ecosystems. Ecosystems 14:1196-1215.

Roy, L.D., J.B. Stelfox, and J.W. Nolan. 1995. Relationships between mammal biodiversity, stand age and structure in Aspen mixedwood forests in Alberta. pp. 159-186 In: J.B. Stelfox (ed.). Relationships between stand age, stand structure, and biodiversity in
Aspen mixedwood forests in Alberta. Jointly published by Alberta Environmental Center (AECV95-R1), Vegreville, AB, and Canadian Forest Service (Project No. 0001A), Edmonton, AB.

Seville, R.S., N.L. Stanton, and D. Spildie. 1997. Long term responses of small mammal communities to the 1998 Huckleberry Mountain fire. University of Wyoming National Park Service Research Station Annual Report 21:64-67. http://repository.uwyo.edu/cgi/viewcontent.c gi? article $=1247 \&$ context $=$ uwnpsrc reports

Spildie, D.R. 1994. The density and distribution of small mammals in Grand Teton National Park, Wyoming. M.S. Thesis, University of Wyoming, Laramie, Wyoming.

Stanton, N.L., S.W. Buskirk, and S.L. Miller. 1990. Habitat distributions of small mammal communities in Grand Teton National Park. University of Wyoming - National Park Service Research Station Annual Report 14:109-115.

http://repository.uwyo.edu/cgi/viewcontent.c gi? article $=1305 \&$ context $=$ uwnpsrc_reports

Stanton, N.L., S.W. Buskirk, D.R. Spildie, and S.L. Miller. 1991. Habitat distributions of small mammal communities in Grand Teton National Park. University of Wyoming National Park Service Research Station Annual Report 15:169-174. http://repository.uwyo.edu/cgi/viewcontent.c gi? article $=1835 \&$ context $=$ uwnpsrc_reports

Stanton, N.L., R.S. Seville, S.W. Buskirk, and S.L. Miller. 1998. Captures and recaptures of small mammals to assess responses to fire in a coniferous forest in the Greater Yellowstone area. University of Wyoming National Park Service Research Station Annual Report 22:71-77. http://repository.uwyo.edu/cgi/viewcontent.c gi? article $=1235 \&$ context $=$ uwnpsrc reports

Stapp, P. 1997. Habitat selection by an insectivorous rodent: patterns and mechanisms across multiple scales. Journal of Mammalogy 78:1128-1143.

Taylor, D.L. 1973. Some ecological implications of forest fire in Yellowstone National Park, Wyoming. Ecology 54:1394-1396.

Wallace, L.L. 2004. After the Fires: The Ecology of Change in Yellowstone National Park. Yale University Press, New Haven, Connecticut. 
Walsh M., and M.A. Haseeb. 2015. Modeling the ecologic niche of plague in sylvan and domestic animal hosts to delineate sources of human exposure in the western United States. PeerJ, 3: e1493.

Williams, R.B., P. Thebo, R.N. Marshall, and J.A. Marshall. 2010. Coccidian oöcysts as typespecimens: Long-term storage in aqueous potassium dichromate solution preserves DNA. Systematic Parasitology 6:69-76.
Wolff, J.O., and Dueser, R.D. 1986. Non-competitive coexistence between Peromyscus species and Clethrionomys gapperi. Canadian FieldNaturalist 100:186-191.

Zollner, P.A., and K.J. Crane. 2003. Influence of canopy closure and shrub coverage on travel along coarse woody debris by eastern chipmunks (Tamias striatus). American Midland Naturalist 150:151-157. 